\title{
Natural Resources-Tribal Right to Life
}

\author{
Dr. Gatti Yellaiah ${ }^{1^{*}}$ \\ ${ }^{1}$ Assistant Director, Dr. BRAOU, Regional Study Centre, Government Degree College (A), Siddipet, \\ Telanhana, India \\ * Gatti Yellaiah, Assistant Director, Dr. BRAOU, Regional Study Centre, Government Degree College \\ (A), Siddipet, Telanhana, India
}

\begin{abstract}
The tribal are booned to use natural resource, but not to distruct the resources. Since they are the dependent on nature, several times there is a chance to destruct nature in their hands. They have enjoyed the right of land, forest, and water as the natural right. The tribal have the communal right. These resources will play a key role in the development of the country. We need to protect these resources. It is the responsibility of all the people, but the greed of man is leading to the destruction of the natural resources throughout the world. Natural resources are not the commony property.
\end{abstract}

\section{Keywords}

tribal, natural resources, destruct, right, development, protect

\section{Introduction}

Tribals enjoyed the rights to land, forest, and water as their natural rights. Every Trbal community has its own customary laws and provisions as to the administration and control over the land, forest, water and society at large, Customary laws are the dynamic traditions where decisions are taken collectively and consensually. These laws are still operative in the scheduled areas.

Till the end of the last century, about 80 percent of India's natural resources were common property. The Common Property Resources (CPR) formed the backbone of India's economy which was predominantly a non-cash and non-market economy.

Around 1865 the British Started the process of expropriating CPRs in India by bringing then under State Central. This was done by crating numerous permanent settlement on common properly land declaring many areas as "reserved forests" "protected forests" and Revenue land. The tibal follow environmental conservation rule. They harvest edible plants which establish ecological wisdom.

\section{Objectives}

The main objectives of this research article is to study the condition of natural resources and the right of Tribal who has been livig in the jungles. 


\section{Research Method}

For reseach method the data has completely collected based on the secondary sources, and a few data is collected from the observation of the researcher by visiting the cite.

\section{Discussion}

For protect the tribal right has a framework. The tibal are strengthened by the Act Recognition of Forest Act,2006. This will protects the individual and as well as community rights of the tribal who live in the forest areas, and has a bood to protect when they are displaced. By providing the right of land to the local people will strenghten indiginous communities. It will support and enhance thir livelihood. It not only increase their income but also help us inguarding the forest cover.

The forest department seems to have overlooked the fact that human communities have lived in or near the forest for innumerable centuries. Certain Human Rights arise from such historical association of man with his habitat. Legislation can not over look history and the natural rights of the tribals.

It is ironical that the urban occupiers of houses are protected by Rent Act against eviction but the forest laws turned the original forest dwellers into second class citizens. In 1984 the traditional rights of the tribals were no longer recognized as rights they became rights and privileges, in 1952 they became rights and concessionals and now they have become merely concessions.

It is noteworthy that section 4 of the Indian Forest Act 1927 provides for an elaborate machinery to acquire any common land as government land. The forest settlement officer is mandated to settle the claims of any individual who may claim a right over any land as his private property within stipulated period of three months (U/S Sec.5).

Moreover, where private property rights are claimed under the Forest Act: the Government can further invoke the Land Acquisition Act 1894, to acquire land for "public purpose”. In effect this takes away the rights of the forest dwellers.

It is clear that the right to life at the individual level and the human right of maintaining the identity at the community level in the case of tribals have been ignored in our Forest Laws. Therefore, these laws are not in consonance with the spirit of our constitution.

But since the state itself was a party in this deal, there was no change in it even after the constitution was adopted and the situation remains as it was before it. "In this way the constitutional provisions for protection of tribal people as also the human rights have been ignored in the system of management of forests adopted in our country.

Tribal societies are victims of development projects taken up by the state. The major threat to livelihood of tribal communities is because of large scale alienation of their lands by the machinery of the state for the construction of mega projects such as large dams, mines, industries, highways etc.

During the period 1951-90 about 40.09 percent of tribals were displaced under different development project in tribal areas India. The increasing threat their livelihood is due to indiscriminate plunder of their environment in relation to land, water and forest resources.

Published by SCHOLINK INC. 
On the other hand the state government is trying to amend tribal protective land transfer regulations 1 of 70 which prohibits the transfer of lands not only between tribals and non-tribals but also among the non-tribals in the scheduled areas of Andhra Pradesh.

What the Government of Andhra Pradesh is now proposing to do amounts to invitation of multinational companies and private agencies to exploit the mineral wealth deposits in the tribal belt at the cost of tribals survival and ecology.

The attempt are in the back drop of decision given by Supreme Court in Samata Case. The supreme Court has prohibited the state Government to transfer its land to non-tribals for any kind of mining activity. It has brought the state under the purview of 1 of 70 regulations considering it as a person.

\section{Conclusion}

Human right should give guarantee for people necessary needs to satisfy their basic needs like house, food, shelter, and education. They have the right to utilise all the advantages of it. The tribal socities do not follow any of the social rules. They have a rich oral tradition. We need to portect as a human right since they are the part of society.

\section{References}

Asia Forest Network www.asiaforestnetwork.org

Centre for International Forestry Research www.cgiar.org/cifor

Forest Conservation Portal www.forests.org

Forest Ethics www.forestethics.org

Forest Trends www.forest-trends.org

International Institute of Environment and Development-Forestry www.iied.org/NR/forestry/index.html

International Union of Forestry Research Organisations http://iufro.boku.ac.at/iufro ProForest www.proforest.net

United Nations Forum on Forests www.un.org/esa/forests

World Rainforest Movement www.wrm.org.uy 